Note

\title{
REFERENCE EVAPOTRANSPIRATION ESTIMATION INSIDE GREENHOUSES
}

\author{
Carolina Fernandes $^{1 *}$; José Eduardo Corá ${ }^{1}$; Jairo Augusto Campos de Araújo² \\ ${ }^{l}$ UNESP/FCAV - Depto. de Solos e Adubos - Via de Acesso Prof. Paulo Donato Castellane, s/n - 14884-900 - \\ Jaboticabal, SP - Brasil. \\ ${ }^{2}$ UNESP/FCAV - Depto. de Engenharia Rural. \\ *Corresponding author <carol@fcav.unesp.br>
}

\begin{abstract}
Because of the large area occupied by a class A pan, alternative methods have been sought to estimate reference evapotranspiration (Eto) inside greenhouses. The objective of this work was to compare ETo estimated by different methods inside and outside a greenhouse. A class A pan (CAP $)$, a reduced pan $(\mathrm{RP})$ and an atmometer $\left(\mathrm{A}_{\mathrm{i}}\right)$ were installed inside a greenhouse, and another class $\mathrm{A}$ pan $\left(\mathrm{CAP}_{\mathrm{o}}\right)$ was installed outside. ETo estimates, obtained by $\mathrm{CAP}_{\mathrm{i}}, \mathrm{RP}_{\mathrm{i}}$, and $\mathrm{A}_{\mathrm{i}}$ were $56 \%, 69 \%$ and $63 \%$ of those estimated by $\mathrm{CAP}_{\mathrm{p}}$, respectively. A simple linear regression showed positive coefficients $R=0.94$ for the $\mathrm{RP}_{\mathrm{i}}$ and the $\mathrm{CAP}_{\mathrm{i}}$, $\mathrm{R}=0.91$ for the $\mathrm{A}_{\mathrm{i}}$ and the $\mathrm{CAP}_{\mathrm{i}}, \mathrm{R}=0.70$ for the $\mathrm{CAP}_{\mathrm{i}}$ and the $\mathrm{CAP}_{\mathrm{o}}, \mathrm{R}=0.66$ for the $\mathrm{RP}_{\mathrm{i}}$ and the $\mathrm{CAP}_{\mathrm{o}}$, and $\mathrm{R}=0.62$ for the $\mathrm{A}_{\mathrm{i}}$ and the CAP . ETo needs to be estimated inside greenhouses and it is possible to use reduced pans or atmometers to estimate the ETo inside the greenhouse. Equipment replacement would increase the available space inside the greenhouse.

Key words: class A pan, reduced pan, atmometer

\section{EVAPOTRANSPIRAÇÃO DE REFERÊNCIA ESTIMATIVA EM CASAS DE VEGETAÇÃO}

\begin{abstract}
RESUMO: Em função da área ocupada pelo tanque classe A, tem-se procurado utilizar métodos alternativos para a estimativa da evapotranspiração de referência (ETo) dentro de casas de vegetação. O trabalho teve como objetivo comparar a ETo estimada pelo método do tanque classe A instalado dentro (TCA $)$ e fora $\left(\mathrm{TCA}_{\mathrm{f}}\right)$ da casa de vegetação e pelos métodos do tanque reduzido (TRED) e do atmômetro (ATM) instalados dentro da casa de vegetação. Os valores estimados da ETo foram comparados por análises de regressão linear simples. ETo estimada pelo TCA, TRED e ATM correspondeu a 56\%, 69\% e 63\% da ETo estimada pelo $\mathrm{TCA}_{\mathrm{f}}$, respectivamente. As regressões entre os valores das ETo estimados pelo TCA $\mathrm{d}$ e pelos outros dois métodos apresentaram valores do coeficiente de correlação $(\mathrm{R})$ de 0,94 para o método do TRED e de 0,91 para o método do ATM. As regressões entre os valores das ETo estimados pelo $\mathrm{TCA}_{\mathrm{f}}$ e aqueles estimados dentro da mesma pelos diferentes métodos, apresentaram valor de $\mathrm{R}$ de 0,70 para o método do TCA , de 0,66 para o método do TRED e de 0,62 para o método do ATM. Além da necessidade de estimar a ETo dentro da casa de vegetação, há possibilidade de substituir o tanque classe A pelo tanque reduzido ou pelo atmômetro para tal estimativa, aumentando assim a área útil da casa de vegetação.

Palavras-chave: tanque classe A, tanque reduzido, atmômetro
\end{abstract}

\section{INTRODUCTION}

Production of seedlings of several species and cultivation of ornamentals and vegetables in greenhouses in Brazil occupies an area of approximately 1000 ha (Oliveira, 1995). The need to provide fresh and good quality products during long periods throughout the year lead to the adoption of this technology (Andriolo, 1999), so protected cropping has become a very popular production system in horticulture.

The plastic covering utilized on greenhouses significantly changes the radiation balance relatively to the external environment, because of the attenuation (absorp- tion and reflexion) of the incident solar radiation, resulting in a reduction of the internal radiation balance and, consequently, affecting evapotranspiration (Sentelhas, 2001). The difference between internal and external evapotranspiration varies according to meteorological conditions. Usually, evapotranspiration inside a greenhouse is around 60 to $80 \%$ of that verified outside (Montero et al., 1985; Rosenberg et al., 1989). Farias et al. (1994) observed that the reference evapotranspiration (Eto) inside greenhouses was always lower, ranging on 45 to $77 \%$ of that verified outside. Braga \& Klar (2000) observed that the values of reference evapotranspiration were 85 and $80 \%$ of the reference evapotranspiratoin veri- 
fied outside for greenhouses oriented east/west and north/ south, respectively.

Reference evapotranspiration can be estimated by several methods, and the class A pan method has been one of the most utilized methods worldwide because of its simplicity, relatively low cost, and yielding of daily evapotranspiration estimates. Greater precision, however, can be obtained when it is utilized for periods of at least five days (Marouelli et al., 1996). However, its use inside greenhouses is still object of controversy. Research results about what pan coefficient $(\mathrm{Kp})$ should be utilized inside the greenhouse are not conclusive. In addition, some producers consider leaving an unproductive area of approximately $10 \mathrm{~m}^{2}$ occupied by the class A pan inside the greenhouse not viable.

$\mathrm{Kp}$ is calculated based on wind speed, size of the border crop and relative humidity (Doorenbos \& Pruitt, 1976). To select a Kp these variables can be easily measured inside a greenhouse. However, Prados (1986) cited by Farias et al. (1994), while working with tomato plants in a greenhouse covered with low-density polyethylene, observed similarity between obtained $\mathrm{K}$ values (a product of $\mathrm{Kp}$ and $\mathrm{Kc}$ - crop coefficient) and Kc values found in the bibliography, and that led the author to conclude that $\mathrm{Kp}$ inside greenhouses must be very close to 1.0.

Because of the large area occupied by a class A pan, alternative methods have been sought to estimate ETo inside greenhouses. Among them, the reduced-size pan and the atmometer deserve special attention. Comparing ETo values estimated by different methods, Farias et al. (1994), observed coefficients of determination equal to 0.54 , between ETo estimated by the class A pan installed inside a greenhouse and ETo estimated by the same method, but outside the greenhouse; 0.72 , between ETo estimated by the reduced pan inside and ETo estimated by the class A pan outside; and, 0.81, between ETo estimated by the reduced pan and ETo by the class A pan, both installed inside. Based on these observations, Farias et al. (1994) indicated the possibility of installing the reduced pan inside the greenhouse to estimate ETo, instead of using the class A pan.

Medeiros et al. (1997) verified that evaporation (E) in reduced pan was on average $15 \%$ greater than in class A pan, when both were installed inside a greenhouse. The authors verified coefficients of correlation equal to 0.88 , between $\mathrm{E}$ in the class A pan installed inside and $\mathrm{E}$ in the class A pan installed outside; 0.89 , between $\mathrm{E}$ in the reduced pan installed inside and $\mathrm{E}$ in the class A pan installed outside; and, 0.96, between $\mathrm{E}$ in the reduced pan and $\mathrm{E}$ in the class $\mathrm{A}$ pan, both installed inside the greenhouse. Similar results were obtained by Menezes Jr. et al. (1999).

Keeping in mind the influence exerted by climate elements on ETo estimation, it is believed that the variations found are related to different climatic conditions un- der which the experiments were conducted. Therefore, the importance of conducting this type of research for regions showing distinct climates must be emphasized. The objective of this work was to compare reference evapotranspirations estimated by different methods, inside and outside a greenhouse, for the region of Jaboticabal, SP, Brazil.

\section{MATERIAL AND METHODS}

The experiment was conducted in Jaboticabal, SP, Brazil. The local altitude is $595 \mathrm{~m}$, with latitude $21^{\circ} 15^{\prime} 22^{\prime \prime} \mathrm{S}$ and longitude $48^{\circ} 18^{\prime} 58^{\prime \prime} \mathrm{W}$. The climate, according to Köppen's classification, is subtropical with a dry winter (Cwa), and mean annual precipitation of 1,400 $\mathrm{mm}$, mean annual temperature of $22^{\circ} \mathrm{C}$ and mean relative humidity of $70 \%$.

The greenhouse was built at east-west orientation, constructed of a metallic framework, chapel style, $4 \mathrm{~m}$ tall, $30 \mathrm{~m}$ in length and $10 \mathrm{~m}$ wide, covered with a $100 \mu \mathrm{m}$ transparent polyethylene film treated against ultraviolet radiation, and side walls protected by $30 \%$ black polypropylene shade-netting. During the observations period (91 days), a tomato long-life type hybrid, cultivar "Carmen", was grown, having a cycle from 02/Nov/1999 to $06 / \mathrm{Feb} / 2000$.

A class A pan, a reduced pan and an atmometer were installed in the center of the greenhouse. The class A pan was constructed of nr. 22 galvanized iron sheet, $1.21 \mathrm{~m}$ in diameter and $0.255 \mathrm{~m}$ in depth. The reduced pan was constructed of the same material, but with smaller dimensions, $0.60 \mathrm{~m}$ in diameter and 0.250 in $\mathrm{m}$ depth. Both pans were installed on a wooden pallet $0.15 \mathrm{~m}$ from soil surface. The modified atmometer (Altenhofen, 1985) consists of a ceramic tile covered by a thick piece of green canvas mounted a top a cylindrical water tank. Distilled water is supplied to the tile in the bottom part of the tank by a suction tube. The atmospheric pressure is maintained inside the tank by a small ventilation hole. A transparent plastic tube is mounted laterally to indicate the water level in the tank. By covering the tile with a green piece of canvas, the atmometer simulates the water lost by an irrigated and vigorous alfalfa field (reference evapotranspiration). The atmometer was installed at $1.5 \mathrm{~m}$ from soil surface.

Reference evapotranspiration (Eto) outside the greenhouse was estimated by a similar class A pan installed at a meteorological station, $300 \mathrm{~m}$ away from the experimental area. Readings were performed daily at 7:30am. The daily evaporation values were calculated by the difference between two consecutive readings. The weekly evaporation values were calculated by the sum of seven consecutive days.

ETo, expressed in mm, for the two class A pans and for the reduced pan, was determined by the equation: $\mathrm{ETo}=\mathrm{Kp}$ E, where: $\mathrm{Kp}=$ pan coefficient, $\mathrm{E}=$ pan evapo- 
ration (mm): $\mathrm{CAP}_{\mathrm{i}}$ (inside), $\mathrm{CAP}_{\mathrm{o}}$ (outside), and $\mathrm{RP}_{\mathrm{i}}$ (inside). For $\mathrm{CAP}_{\mathrm{i}}$ the Kp was considered equal to 1.0, as recommended by Prados (1986), cited by Farias et al. (1994). For $\mathrm{CAP}_{\mathrm{o}}$ the $\mathrm{Kp}$ was taken as 0.85 , since the size of the border crop (grass) was $1000 \mathrm{~m}$ and, during the experiment, the weekly value of wind speed was lower than $175 \mathrm{~km}$ day $^{-1}$ and the weekly value of relative humidity remained around 40-70\% (Doorenbos \& Pruitt, 1976). The ETo for the atmometer was determined by its evaporation reading.

The estimated ETo values were: $\mathrm{CAP}_{\mathrm{o}}$, the mean weekly ETo value estimated by the class A pan installed outside the greenhouse $(\mathrm{mm}) ; \mathrm{CAP}_{i}$, the mean weekly ETo value estimated by the class $A$ pan installed inside the greenhouse $(\mathrm{mm})$; $\mathrm{RP}_{\mathrm{i}}$, the mean weekly ETo value estimated by the reduced pan installed inside the greenhouse (mm); and $\mathrm{A}_{\mathrm{i}}$, the mean weekly ETo value estimated by the atmometer installed inside the greenhouse $(\mathrm{mm})$. The weekly ETo values estimated by the different methods and conditions were compared by linear regression analyses.

\section{RESULTS AND DISCUSSION}

The weekly ETo values estimated by $\mathrm{CAP}_{\mathrm{i}}, \mathrm{RP}_{\mathrm{i}}$ and $\mathrm{A}_{\mathrm{i}}$ were lower than those estimated by $\mathrm{CAP}_{\mathrm{o}}$ (Figure 1). Many authors have also observed that evapotranspiration inside greenhouses was lower than outdoor (Farias et al., 1994; Martins et al., 1994; Braga \& Klar, 2000). These results can be explained by the influence of the main factors of evaporative demand of the atmosphere, such as lower wind speed values, higher relative humidity and lower incidence of direct solar radiation inside greenhouses.

The mean weekly ETo value estimated by the $\mathrm{CAP}_{\text {o }}$ was $32 \mathrm{~mm}$, and the mean weekly ETo values estimated inside the greenhouse were different depending on the estimation method, i.e., the weekly ETo was $18 \mathrm{~mm}$ for the $\mathrm{CAP}_{i}, 22 \mathrm{~mm}$ for the $\mathrm{RP}_{\mathrm{i}}$ and $20 \mathrm{~mm}$ for the $\mathrm{A}_{\mathrm{i}}$, which corresponded to $56 \%, 69 \%$ and $63 \%$ of the weekly

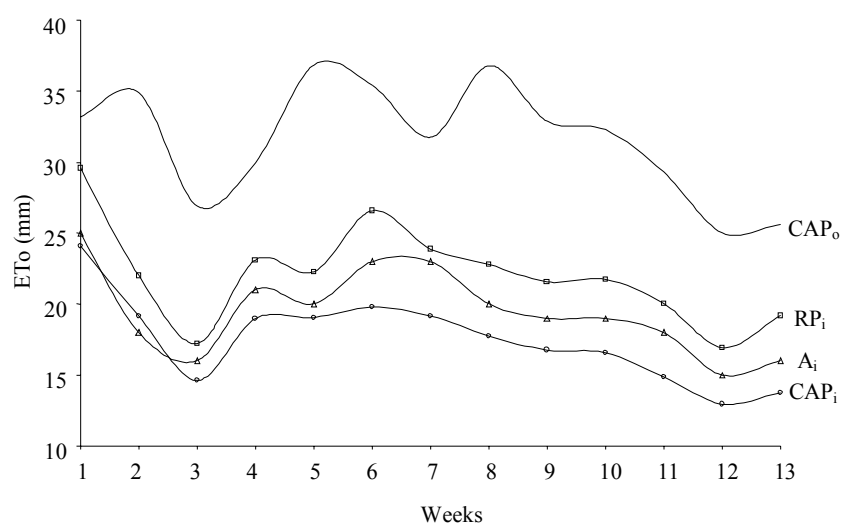

Figure 1 - Weekly values of reference evapotranspiration (ETo) estimated through class A pan installed outside (CAP) the greenhouse and class $\mathrm{A}$ pan $\left(\mathrm{CAP}_{\mathrm{i}}\right)$, reduced pan $\left(\mathrm{RP}_{\mathrm{i}}\right)$ and atmometer $\left(\mathrm{A}_{\mathrm{i}}\right)$ installed inside the greenhouse.
ETo estimated by the $\mathrm{CAP}_{\mathrm{o}}$, respectively. Therefore, inside the greenhouse, weekly ETo values estimated by the different methods can be ranked as follow: reduced pan $>$ atmometer $>$ class A pan. Farias et al. (1994) observed that ETo estimated by the class A pan installed inside the greenhouse was approximately half (54\%) of that estimated outdoors by the same method. The authors also observed that ETo estimated by a reduced pan installed inside the greenhouse was $77 \%$ of that estimated by the class A pan installed outside.

In the present work, the mean weekly ETo value estimated by the $\mathrm{RP}_{\mathrm{i}}$ was $22 \%$ higher than that estimated

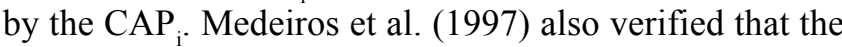
evaporation in a reduced pan was higher than for the class A pan. This fact can be explained by the increase in evaporation with the decrease in water surface, because of aerodynamic factors and to differences in energy transfer between the water surface and the atmosphere (Guttormsen, 1974).

With respect to the atmometer, the weekly ETo values were $11 \%$ higher than those estimated by the class A pan, since both were installed inside the greenhouse. It is believed that this difference might be a consequence of interpretations made while choosing a pan coefficient $(\mathrm{Kp})$ to estimate ETo through by the class A pan. In the case of the atmometer, the ETo estimate is given by its own evaporation, since the presence of the green canvas on the porous tile makes the device simulate the water loss experienced by an irrigated alfalfa field under vigorous growth (reference evapotranspiration).

To determine the relationship between the weekly ETo values estimated by the different methods and conditions, simple linear regression analyses were carried out (Table 1).

Greater coefficients of correlation (R) were observed when comparisons were made between methods for the inside-the-greenhouse condition. With regard to the comparisons between the weekly ETo values estimated by the class A pan and by the other two methods,

Table 1 - Simple linear regression analyses results between weekly reference evapotranspiration (ETo) values, estimated by different methods and conditions.

\begin{tabular}{llcc}
\hline Regression $^{\#}$ & & Adjusted equation & $\mathrm{R}$ \\
\hline $\mathrm{CAP}_{0} \mathrm{X} \mathrm{CAP}_{\mathrm{i}}$ & $\mathrm{CAP}_{\mathrm{i}}=0.8001+0.5283 \mathrm{CAP}_{0}$ & $0.7001 * *$ \\
$\mathrm{CAP}_{0} \mathrm{X} \mathrm{RP}_{\mathrm{i}}$ & $\mathrm{RP}_{\mathrm{i}}=4.0806+0.5690 \mathrm{CAP}_{\mathrm{o}}$ & $0.6586 * *$ \\
$\mathrm{CAP}_{0} \mathrm{X} \mathrm{A}_{\mathrm{i}}$ & $\mathrm{A}_{\mathrm{i}}=4.8007+0.4638 \mathrm{CAP}_{0}$ & $0.6237 * *$ \\
$\mathrm{CAP}_{\mathrm{i}} \mathrm{X} \mathrm{RP}_{\mathrm{i}}$ & $\mathrm{RP}_{\mathrm{i}}=3.1673+1.0799 \mathrm{CAP}_{\mathrm{i}}$ & $0.9433 * *$ \\
$\mathrm{CAP}_{\mathrm{i}} \mathrm{X} \mathrm{A}_{\mathrm{i}}$ & $\mathrm{A}_{\mathrm{i}}=3.7286+0.8989 \mathrm{CAP}_{\mathrm{i}}$ & $0.9122 * *$
\end{tabular}

${ }^{*} \mathrm{CAP}_{\mathrm{o}}=$ mean $\mathrm{ETo}_{\mathrm{CAP}}$ value outside the greenhouse $(\mathrm{mm}) ; \mathrm{CAP}_{\mathrm{i}}=$ mean $\mathrm{ETo}_{\mathrm{CAP}}$ value inside the greenhouse $(\mathrm{mm}) ; \mathrm{RP}_{\mathrm{i}}=$ mean $\mathrm{ETo}_{\mathrm{RP}}$ value inside the greenhouse $(\mathrm{mm}) ; \mathrm{A}_{\mathrm{i}}=$ mean $\mathrm{ETo}_{\mathrm{A}}$ value inside the greenhouse $(\mathrm{mm}) .{ }^{* *}$ significant at $1 \%$. 
inside the greenhouse, a greater coefficient of correlation was obtained for the reduced pan method $(\mathrm{R}=0.94)$, followed by the atmometer method $(\mathrm{R}=0.91)$.

With regard to comparisons between the weekly ETo values estimated by $\mathrm{CAP}_{\mathrm{o}}$ and those estimated by the different methods inside, a greater coefficient of correlation was obtained for the class A pan method $(\mathrm{R}=0.70)$, followed by the reduced pan method $(\mathrm{R}=0.66)$, and by the atmometer method $(\mathrm{R}=0.62)$.

Results in the literature sometimes corroborate and sometimes disagree with results found here in (Farias et al., 1994; Medeiros et al., 1997; Menezes Jr. et al. , 1999). These variations can probably be attributed to different climatic conditions under which the experiments were carried out, thus confirming the importance of conducting this type of research for distinct regions. It is believed that the utilization of adjusted equations with coefficients of correlation smaller than 0.70 to estimate ETo would impart an accumulated error along the period. In this case, the water endowment of the crop would be under or overestimated, and consequently the irrigation management could be jeopardized.

ETo estimated outside the greenhouse shows values higher than those for ETo estimated inside, and these results corroborate those of other authors whose researches were carried out in distinct environments. Therefore, for cropping systems conducted under protected environments, the recommendation for estimating ETo inside the greenhouse is reassured.

Considering the high coefficients of correlation between the estimated weekly ETo values, inside the greenhouse, it is possible to replace the class A pan with the reduced pan or with the atmometer to estimate ETo.

In addition to providing an increase in usable area inside the greenhouse, both the reduced pan and the atmometer involve lower costs and are easier to operate. However, because of the influence of climate elements on ETo estimation, it is believed that the equations should be adjusted for the various climatic conditions. Therefore, for the specific conditions in this study, the utilization of a reduced pan or an atmometer as replacements for the class A pan is recommended to estimate ETo inside the greenhouse in the region of Jaboticabal, as long as the equations adjusted in this experiment are utilized.

\section{ACKNOWLEDGEMENTS}

To CNPq for granting C. Fernandes Scholarship.

\section{REFERENCES}

ALTENHOFEN, J. A modified atmometer for on farm evapotranspiration determination. In: NATIONAL CONFERENCE ON ADVANCES IN EVAPOTRANSPIRATION, Chicago, 1985. Anais. Chicago: ASAE, 1985. p.177-184.

ANDRIOLO, J.L. Fisiologia das culturas protegidas. Santa Maria: UFSM, 1999. 142p.

BRAGA, M.B.; KLAR, A.E. Evaporação e evapotranspiração de referência em campo e estufa orientadas nos sentidos norte/sul e leste/oeste. Irriga, v.5, p.222-228, 2000.

DOORENBOS, J.; PRUITT, W.O. Las necesidades de agua de los cultivos. Roma: FAO, 1976. 193p.

FARIAS, J.R.B.; BERGAMASCHI, H.; MARTINS, S.R. Evapotranspiração no interior de estufas plásticas. Revista Brasileira de Agrometeorologia, v.2, p.17-22, 1994.

GUTTORMSEN, G. Effects of root medium and watering on transpiration, growth and development of glasshouse crops: II. The relationship between evaporation pan measurements and transpiration in glasshouse crops. Plant and Soil, v.40, p.461-478, 1974.

MAROUELLI, W.A.; SILVA, W.L. de C.; SILVA, H.R. da. Manejo da irrigação em hortaliças. 5.ed. Brasília: EMBRAPA, SPI, 1996. 72p.

MARTINS, G.; CASTELLANE, P.D.; VOLPE, C.A. Influência da casade-vegetação nos aspectos climáticos e em época de verão chuvoso. Horticultura Brasileira, v.12, p.131-135, 1994.

MEDEIROS, J.F. de; PEREIRA, F.A. de C.; FOLEGATTI, M.V.; PEREIRA, A.R.; VILLA NOVA, N.A. Comparação entre a evaporação em tanque Classe A padrão e em mini tanque, instalados em estufa e estação meteorológica. In: CONGRESSO BRASILEIRO DE AGrometeorologiA, 10., Piracicaba, 1997. Anais. Piracicaba: ESALQ, 1997. p.228-230.

MENEZES JR., F.O.G.; MARTINS, S.R.; DUARTE, G.B.; FORTES, D.F. Estimativa de evapotranspiração em ambiente protegido mediante a utilização de diferentes evaporímetros. In: CONGRESSO BRASILEIRO DE AGROMETEOROLOGIA, 11.; REUNIÃO LATINO-AMERICANA DE AGrometeorologiA, 2., Florianópolis, 1999. Anais. Florianópolis: Sociedade Brasileira de Agrometeorologia, 1999. p.370.

MONTERO, J.I.; CASTILLA, N.; GUTIERREZ de RAVÉ, E.; BRETONES, F. Climate under plastic in the Almeria. Acta Horticulturae, n.170, p.227-234, 1985.

OLIVEIRA, M.R.V. de. O emprego de casas de vegetação no Brasil: vantagens e desvantagens. Pesquisa Agropecuária Brasileira, v.30, p.1049-1060, 1995.

ROSENBERG, N.J.; McKENNEY, M.S.; MARTIN, P. Evapotranspiration in a greenhouse-warmed world: a review and a simulation. Agricultural and Forest Meteorology, v.47, p.303-320, 1989.

SENTELHAS, P.C. Agrometeorologia aplicada à irrigação. In: MIRANDA, J.H.; PIRES, R.C. de M. Irrigação. Piracicaba: FUNEP, 2001. p.63120 .

$\overline{\text { Received May 17, }} 2002$

Accepted April 28, 2003 